\title{
IN SILICO STUDIES ON SOME DENGUE VIRAL PROTEINS WITH SELECTED ALLIUM CEPA OIL CONSTITUENTS FROM ROMANIAN SOURCE
}

\author{
GABRIELA TATARINGA ${ }^{1 *}$, ADRIAN SPAC ${ }^{1}$, BALASUBRAMANIAN SATHYAMURTHY ${ }^{2}$, \\ ANA MARIA ZBANCIOC ${ }^{1}$ \\ ${ }^{1}$ University of Medicine and Pharmacy "Grigore T. Popa” Iași, Romania \\ ${ }^{2}$ Ramaiah College of Arts, Science and Commerce, Bangalore, Karnataka, India \\ *corresponding author: gtataringa22@yahoo.com \\ Manuscript received: April 2019
}

\begin{abstract}
Onion (Allium cepa) is a famous spice commonly grown all over the world and consumed in various forms. Onion is a source of various biologically active compounds, such as sulphur compounds and flavonoids, derivatives with a large variety of pharmacological activities including anticancer, antidiabetic, antimicrobial, cardiovascular, antioxidant effects. Onion oil is an important source of sulphur compounds. In this study, the binding efficiency of 11 identified compounds from Allium cepa oil with some selected proteins from Dengue virus through in silico method was done. By virtual screening and docking results, we have found that hexadecanoic acid has the most convenient binding activity for the seven selected proteins.
\end{abstract}

\section{Rezumat}

Allium cepa este o plantă utilizată ca și condiment, dar are și importante proprietăți terapeutice. Ceapa reprezintă o sursă importantă de compuși biologic activi precum derivații sulfurați şi flavonoidele, compuși cu proprietăți anticanceroase, antidiabetice, antimicrobiene, cardiovasculare, antioxidante etc. Uleiul volatil de Allium cepa conține o multitudine de compuși organosulfurați. În acest studiu am evaluat eficiența legării a 11 derivați, identificați din uleiul volatil de Allium cepa pentru o serie de proteine ale virusului Dengue. Printr-un screening virtual s-a demonstrat faptul că acidul hexadecanoic se leagă cel mai convenabil de situsurile celor șapte proteine selectate.

Keywords: binding interaction, molecular docking, Dengue virus, Allium cepa

\section{Introduction}

Onion (Allium cepa L.) is one of the oldest nutritive plants, being grown since prehistoric times. It is one of the most important vegetables used worldwide for enhancing the flavour and taste of a variety of foods. Scientific data suggest that the biological and medicinal properties of Allium cepa are correlated with itschemical composition, especially organosulfur and flavonoid constituents.

The phytocomplexes compounds found in onion have the potential to promote health benefits in humans and offer protection from a variety of diseases. The organosulphur compounds have antimicrobial, antiallergenic, anti-inflammatory and antithrombotic activity [1-4]. As well as this, flavonols in onions, such as quercetol and kaempferol also possess different important biological roles like antiviral, antimicrobial, anti-inflammatory and anticancer activity along with protection of the heart and brain [5-7].

The bioactive properties and characteristic flavour of onion have been attributed to its sulphur compounds, which consist in a mixture of mono-, di-, tri- and tetra-sulphides with different alkyl groups and they are present in the volatile fraction [2].

Limited available data exhibit inhibitory effects of onion against different viruses as human immunodeficiency virus (HIV), herpes simplex virus type 1, poliovirus type 1 , para-influenza virus type 3 and potato virus [8].

Dengue viruses (DENVs) cause the most common arthropod-borne viral disease in humans with 50 - 100 million infections per year. DENV infection can be asymptomatic or a self-limited, acute febrile disease ranging in severity. The classical form of Dengue fever (DF) is characterized by high fever, headache, stomachache, rash, myalgia, and arthralgia [9].

There are ten proteins identified for this virus, out of which three are structural proteins and seven are non-structural proteins [10]. The seven non-structural proteins are NS1protein, NS2B/NS3 protease, trans membrane domain of NS2A, NS3 helicase, envelope protein, capsid protein, and NS5 protein [11, 12]. NS2B-NS3 protease is a crucial enzyme for the viral replication. The N-terminal of the NS3 protein will 
associate with the NS2B cofactor that is important for the viral replication. The structural protein of Dengue virus is the envelope protein which is involved in the viral assembly.

Despite intensive research, the underlying mechanisms causing severe Dengue is still not well understood partly due to the lack of appropriate animal models of infection and disease. Protein Data Bank (PDB) is a protein storage bioinformatics tool that contains the structures of large numbers of proteins, ligands and other macromolecules [13-15]. Docking analysis could be conducted for the protein and the ligand to analyse the fitness and the interaction with each other in the form of binding energy. Docking is a method which predicts the preferred orientation of one molecule to a second when bound to each other to form a stable complex $[16,17]$.

It is well known that plants are a rich source of bioactive compounds without harmful side-effects, thus it is an increased interest to identify new potential candidates against Dengue virus from plants [18].

The aim of our study was to compare the best docking fit for the selected Allium cepa oil constituents with the Dengue viral proteins. This interaction could be useful to develop potential chemical entities for the treatment of Dengue fever.

\section{Materials and Methods}

\section{Materials}

Allium cepa oil extraction

Allium cepa oil was extracted by steam distillation. The vegetal product was chopped in small pieces and mashed with domestic blender. The sample was transferred into a flask and mixed with distilled water (1:1.5 ratio) and the Neo Clevenger apparatus was installed. The mixture was heated during $4 \mathrm{~h}$ and the essential oil (yellow liquid) was collected and stored in at $4^{\circ} \mathrm{C}$.

Analysis was performed by gas chromatography mass spectrometry (HP 5890 Serie II gas chromatography system) using a mass selective detector (HP 5971) and HP-5MS column $(25 \mathrm{~m} \times 0.250 \mathrm{~mm}$ internal diameter; film thickness, $0.25 \mu \mathrm{m})$. The oven temperature was held at $30^{\circ} \mathrm{C}$ for 2 minutes, heated to $150^{\circ} \mathrm{C}$ at $6^{\circ} \mathrm{C} / \mathrm{min}$, heated to $150 \mathrm{C}$ for 2 minutes and then to $250^{\circ} \mathrm{C}$ at $10^{\circ} \mathrm{C} / \mathrm{min}$. The carrier gas was helium with a flow rate $1 \mathrm{~mL} / \mathrm{min}$.
The compounds were identified by comparison with spectra from the library Wiley $275 \mathrm{~L}$.

Preparation of Dengue viral proteins:

The protein data bank (PDB) was used to obtain the three-dimensional structure of the macromolecule [14]. The structures are downloaded and saved either in mm CIF or PDB format. Proteins of Dengue virus were used for this study. The 3D structure of all the seven proteins were downloaded from PDB and saved in PDB format. The downloaded proteins were viewed in Py-Mol 1.7.x viewer.

Preparation of ligands

Following GS-MS analysis on Romanian onion oil, we selected 11 ligands for this study, namely: methyl, propyl disulphide, 1-methylethyl propyl disulphide, dimethyl trisulphide, dipropyldisulphide, 2-propenylpropyl disulphide, dimethyl disulphide, cis propenyl propyl trisulphide, 3-mercaptopropionic acid, bis (1methylethyl) disulphide, S-propyl L-cysteine, hexadecanoic acid, noted A-K. Ligands were constructed using ChemSketch freeware version. The constructed ligands were optimized to add the hydrogen bonds and the obtained structures were saved in .mol files for docking analysis and named as A, B and C respectively.

Docking study

Docking studies were conducting using iGEMDOCK version 2.1. software. The proteins and the ligands were loaded and the out path was set. Standard docking parameters were used for docking (population size = 200 , generations $=70$ and number of solutions $=2$ ) . The docking process was initiated. After the docking process, the best docking pose for the individual ligands can be obtained for all the seven Dengue viral proteins.

\section{Results and Discussion}

The GC-MS study of onion oil showed that the most important components are sulphur-containing organic compounds, especially sulphides, which are responsible for the characteristic odour (Table I). We noted that tri- and disulphides were predominant and monosulphides are not detected in the analysed sample. Among trisulphides the major component was propenyl, propyl trisulphide, dipropyl disulphide, bis (1-methylethyl) disulphide and 1-methylethyl propyl disulphide were predominant disulphide components present in the volatile oil analysed.

Table I

The compounds identified in Allium cepa L. essential oil

\begin{tabular}{|c|c|c|}
\hline Compound & Retention time (min) & Area \% \\
\hline Methyl, propyl disulphide & 9.62 & 0.71 \\
\hline Mehanthiol & 2.66 & 0.1 \\
\hline Dimethyl trisulphide & 10.74 & 0.49 \\
\hline 3,4 and 2,4- Dimethyl-thiophene & 8.92 & 2.50 \\
\hline 1-Methylethyl, propyl disulphide & 14.60 & 3.40 \\
\hline
\end{tabular}


FARMACIA, 2020, Vol. 68, 1

\begin{tabular}{|c|c|c|}
\hline Compound & Retention time (min) & Area \% \\
\hline bis(1-methylethyl) disulphide & 14.60 & 3.40 \\
\hline Dipropyl disulphide & 14.60 & 3.40 \\
\hline 2-Propenyl, propyl disulphide & 14.83 & 1.41 \\
\hline 3-Amino-2-thioxo-4-thiazolidinone & 14.83 & 1.41 \\
\hline 4,5-Dimethyl -isothiazole & 15.30 & 0.52 \\
\hline Di-thioallyl propionate & 14.97 & 0.43 \\
\hline 1,3,5-Trithiane & 15.96 & 0.67 \\
\hline Ethylthio- benzene & 15.96 & 0.67 \\
\hline 3-(Methylthio)- propene & 16.22 & 0.59 \\
\hline Isothiocyanato-methane & 16.11 & 0.35 \\
\hline Dimethyl disulphide & 16.22 & 0.59 \\
\hline 1,1-bis (Methylthio)-ethane & 16.33 & 0.32 \\
\hline (S)-(+)-2-Ethyltetrahydrofurane & 16.95 & 0.83 \\
\hline 3,3'-Bitiofene & 17.96 & 1.09 \\
\hline Methyl-1-(methylthio) propyl-disulphide & 18.61 & 1.10 \\
\hline 1,2,4-Dithiazolidin-3-one & 19.81 & 0.58 \\
\hline Propenyl, propyl trisulphide & 20.49 & 46.05 \\
\hline 3,5-Diethyl-1,2,4-trithiolane & 20.70 & 23.50 \\
\hline 6,8-Dioxabicyclo(3.2.1)octan-2.beta.-ol-3 & 9.88 & 1.69 \\
\hline 2-(Methylthio)-butane & 22.36 & 0.65 \\
\hline Thiazolidine & 23.78 & 0.57 \\
\hline 3Mercaptopropionic acid & 24.02 & 0.54 \\
\hline Trans, trans-farnesol & 25.76 & 1.22 \\
\hline S - propyl - L- cysteine & 28.43 & 0.16 \\
\hline Hexadecanoic acid & 29.21 & 0.23 \\
\hline 2,4,6-D-3-phenyl- isocianide & 31.79 & 0.96 \\
\hline Thiophene & 6.34 & 0.28 \\
\hline
\end{tabular}

This essential oil is similar in chemical composition to that found by Mnayer et al. The difference in composition found on the essential oil investigated is likely to be related to abiotic factors such as climate-specific regions of the sample origin and geographical factors such as soil type [19].

Among the identified compounds by GS-MS, it has been selected a number of 11 derivatives with various structures, sulphides, acids, etc. (Table II).

Table II

Compounds selected for docking experiments

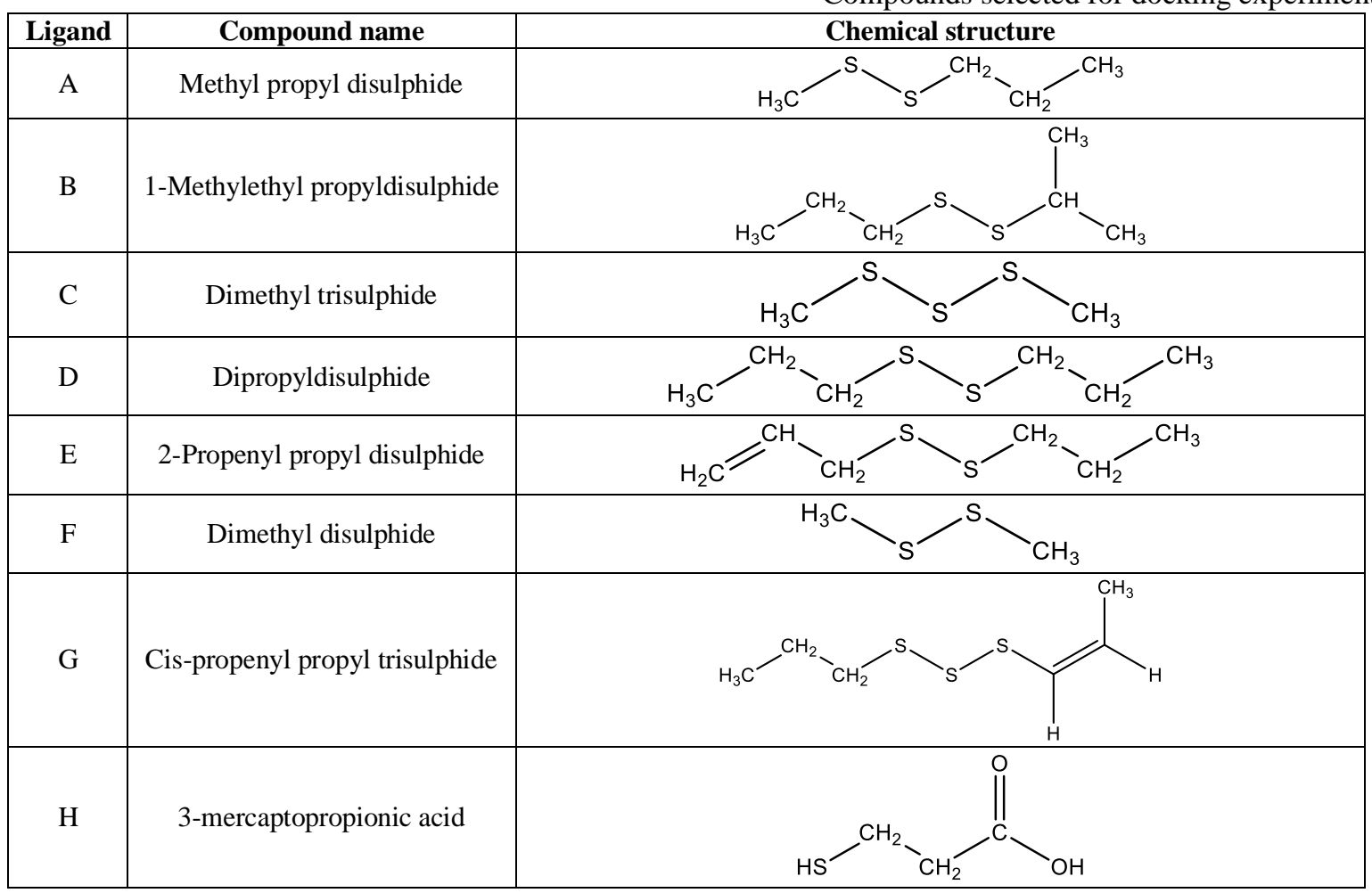


FARMACIA, 2020, Vol. 68, 1

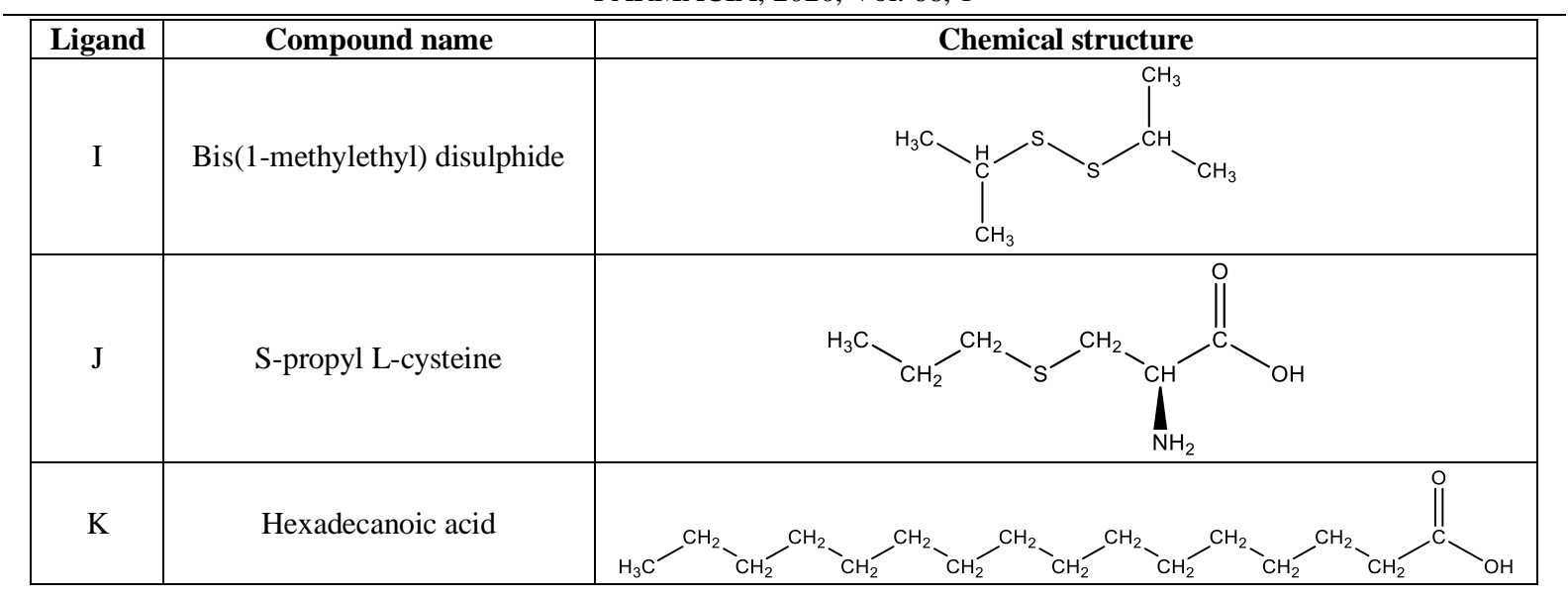

Table III shows the binding energy calculations in which, compound $\mathrm{K}$ exhibited the maximum interaction energy. In contrast, dimethyl disulphide showed the least interaction energy compared to all other ligands. The binding mechanism between proteins and small molecules like drugs involves several bonds such as hydrophobic force, hydrogen bonds, electrostatic interactions and van der Waals interactions [20].

The Van der Waals force is a transient, weak electrical attraction of one atom to another. Van der Waals attractions exist because every atom has an electron cloud that can fluctuate, yielding a temporary electric dipole. The van der Waals forces may seem insignificant because of their weak character.
Hydrogen bonds occur between an $\mathrm{H}$ and two strongly negatively-charged groups (e.g., N, O, F). A single hydrogen bond is weaker than the electrostatic forces, but when several hydrogen bonds occur simultaneously, they can increase the strength and stability of a drugreceptor interaction substantially.

In Tables IV and V there are presented the van der Waals forces values and $\mathrm{H}$-bond profile for Dengue virus proteins with the investigated ligands.

The interactions of the designed compounds with the amino acids in the active site of proteins are listed in Table VI.

Table III

The total binding energy $(\mathrm{kcal} / \mathrm{mol})$ profile for Dengue virus proteins with the investigated ligands

\begin{tabular}{|c|c|c|c|c|c|c|c|}
\hline Ligand & $\begin{array}{c}\text { Capsid } \\
\text { protein }\end{array}$ & $\begin{array}{c}\text { Envelope } \\
\text { protein }\end{array}$ & $\begin{array}{c}\text { NS1 } \\
\text { protein }\end{array}$ & $\begin{array}{c}\text { NS2A } \\
\text { protein }\end{array}$ & $\begin{array}{c}\text { NS2B-NS3 protease } \\
\text { protein }\end{array}$ & $\begin{array}{c}\text { NS3 helicase } \\
\text { protein }\end{array}$ & $\begin{array}{c}\text { NS5 } \\
\text { protein }\end{array}$ \\
\hline A & -42.27 & -35.62 & -44.26 & -272.57 & -35.71 & -43.77 & -36.99 \\
\hline B & -48.34 & -43.38 & -56.91 & -346.85 & -44.52 & -48.32 & -49.53 \\
\hline C & -37.05 & -30.33 & -37.99 & -233.03 & -28.88 & -35.35 & -33.44 \\
\hline D & -53.93 & -41.79 & -57.65 & -363.47 & -45.42 & -47.89 & -52.02 \\
\hline E & -56.99 & -48.85 & -56.23 & -387.97 & -48.95 & -58.26 & -51.23 \\
\hline F & -31.64 & -29.03 & -31.66 & -203.11 & -25.88 & -30.46 & -29.01 \\
\hline G & -55.86 & -48.43 & -56.89 & -384.29 & -49.62 & -55.22 & -52.41 \\
\hline H & -51.14 & -45.29 & -50.74 & -257.63 & -39.37 & -59.08 & -51.3 \\
\hline I & -51.31 & -41.59 & -51.37 & -300.56 & -43.91 & -49.62 & -50.85 \\
\hline J & -65.18 & -66.62 & -71.41 & -441.29 & -65.42 & -69.84 & -67.51 \\
\hline K & -83.65 & -78.06 & -86.84 & -451.87 & -94.56 & -104.48 & -78.26 \\
\hline
\end{tabular}

Table IV

Van der Waal's force (kcal/mol)

\begin{tabular}{|c|c|c|c|c|c|c|c|}
\hline Ligand & $\begin{array}{c}\text { Capsid } \\
\text { protein }\end{array}$ & $\begin{array}{c}\text { Envelope } \\
\text { protein }\end{array}$ & $\begin{array}{c}\text { NS1 } \\
\text { protein }\end{array}$ & $\begin{array}{c}\text { NS2A } \\
\text { protein }\end{array}$ & $\begin{array}{c}\text { NS2B-NS3 protease } \\
\text { protein }\end{array}$ & $\begin{array}{c}\text { NS3 helicase } \\
\text { protein }\end{array}$ & $\begin{array}{c}\text { NS5 } \\
\text { protein }\end{array}$ \\
\hline A & -42.27 & -35.62 & -44.26 & -272.57 & -35.71 & -43.77 & -36.99 \\
\hline B & -48.34 & -43.38 & -56.91 & -346.85 & -44.52 & -48.32 & -49.53 \\
\hline C & -37.05 & -30.33 & -37.99 & 233.03 & -28.88 & -35.35 & -33.44 \\
\hline D & -53.93 & -41.79 & -57.65 & -363.47 & -45.42 & -47.89 & -52.02 \\
\hline E & -56.99 & -48.85 & -56.23 & -387.97 & -48.95 & -58.06 & -51.23 \\
\hline F & -31.64 & -29.03 & -31.66 & -203.11 & -25.88 & -30.46 & -29.01 \\
\hline G & -55.86 & -48.43 & -56.89 & -384.29 & -49.62 & -55.22 & -52.41 \\
\hline H & -26.06 & -30.16 & -39.41 & -229.92 & -25.48 & -31.53 & -28.64 \\
\hline I & -51.31 & -41.59 & -51.37 & -300.56 & -43.91 & -49.62 & -50.85 \\
\hline J & -56.15 & -46.63 & -54.17 & -406.29 & -51.57 & -48.27 & -48.71 \\
\hline K & -81.44 & -64.76 & -65.13 & -422.31 & -74.54 & -77.1 & -6.4 \\
\hline
\end{tabular}


Table V

$\mathrm{H}$-bond profile for Dengue virus proteins with the investigated ligands

\begin{tabular}{|c|c|c|c|c|c|c|c|}
\hline Ligand & $\begin{array}{l}\text { Capsid } \\
\text { protein }\end{array}$ & $\begin{array}{c}\text { Envelope } \\
\text { protein }\end{array}$ & $\begin{array}{c}\text { NS1 } \\
\text { protein }\end{array}$ & $\begin{array}{c}\text { NS2A } \\
\text { protein }\end{array}$ & $\begin{array}{c}\text { NS2B-NS3 protease } \\
\text { protein }\end{array}$ & $\begin{array}{l}\text { NS3 helicase } \\
\text { protein }\end{array}$ & $\begin{array}{c}\text { NS5 } \\
\text { protein }\end{array}$ \\
\hline $\mathrm{A}$ & - & - & - & - & - & - & - \\
\hline $\mathrm{B}$ & - & - & - & - & - & - & - \\
\hline $\mathrm{C}$ & - & - & - & - & - & - & - \\
\hline $\mathrm{D}$ & - & - & - & - & - & - & - \\
\hline$E$ & - & - & - & - & - & - & - \\
\hline $\mathrm{F}$ & - & - & - & - & - & - & - \\
\hline $\mathrm{G}$ & - & - & - & - & - & - & - \\
\hline $\mathrm{H}$ & $\begin{array}{l}\mathrm{H}-\mathrm{M} \\
\mathrm{H}-\mathrm{S} \\
\end{array}$ & H-M & $\begin{array}{l}\mathrm{H}-\mathrm{M} \\
\mathrm{H}-\mathrm{S} \\
\end{array}$ & H-M & $\begin{array}{l}\mathrm{H}-\mathrm{M} \\
\mathrm{H}-\mathrm{S} \\
\end{array}$ & $\begin{array}{l}\mathrm{H}-\mathrm{M} \\
\mathrm{H}-\mathrm{S} \\
\end{array}$ & $\begin{array}{l}\mathrm{H}-\mathrm{M} \\
\mathrm{H}-\mathrm{S} \\
\end{array}$ \\
\hline $\mathrm{I}$ & - & - & - & - & - & - & - \\
\hline $\mathrm{J}$ & - & $\begin{array}{l}\mathrm{H}-\mathrm{M} \\
\mathrm{H}-\mathrm{S} \\
\end{array}$ & $\begin{array}{l}\mathrm{H}-\mathrm{M} \\
\mathrm{H}-\mathrm{S} \\
\end{array}$ & H-M & $\begin{array}{l}\mathrm{H}-\mathrm{M} \\
\mathrm{H}-\mathrm{S} \\
\end{array}$ & $\begin{array}{c}\mathrm{H}-\mathrm{M} \\
\mathrm{H}-\mathrm{S} \\
\end{array}$ & $\begin{array}{c}\mathrm{H}-\mathrm{M} \\
\mathrm{H}-\mathrm{S} \\
\end{array}$ \\
\hline $\mathrm{K}$ & $\begin{array}{c}\mathrm{H}-\mathrm{M} \\
\mathrm{H}-\mathrm{S}\end{array}$ & H-M & $\mathrm{H}-\mathrm{S}$ & H-M & $\begin{array}{l}\mathrm{H}-\mathrm{M} \\
\mathrm{H}-\mathrm{S}\end{array}$ & $\begin{array}{c}\mathrm{H}-\mathrm{M} \\
\mathrm{H}-\mathrm{S}\end{array}$ & $\mathrm{H}-\mathrm{S}$ \\
\hline
\end{tabular}

$\mathrm{H}-\mathrm{M}$ is the hydrogen bonding between the viral protein and the main chain of the aminoacid; $\mathrm{H}-\mathrm{S}$ is the hydrogen bonding between the viral protein and the side chain of the aminoacid

Table VI

Amino-acid position/profile for Dengue virus proteins with the investigated ligands

\begin{tabular}{|c|c|c|c|c|c|c|c|}
\hline Ligand & $\begin{array}{l}\text { Capsid } \\
\text { protein }\end{array}$ & $\begin{array}{l}\text { Envelope } \\
\text { protein }\end{array}$ & NS1 protein & $\begin{array}{l}\text { NS2A } \\
\text { protein }\end{array}$ & $\begin{array}{l}\text { NS2B-NS3 } \\
\text { protease } \\
\text { protein }\end{array}$ & $\begin{array}{l}\text { NS3 helicase } \\
\text { protein }\end{array}$ & NS5 protein \\
\hline $\mathrm{A}$ & - & - & - & - & - & - & - \\
\hline $\mathrm{B}$ & - & - & - & - & - & - & - \\
\hline $\mathrm{C}$ & - & - & - & - & - & - & - \\
\hline $\mathrm{D}$ & - & - & - & - & - & - & - \\
\hline$E$ & - & - & - & - & - & - & - \\
\hline $\mathrm{F}$ & - & - & - & - & - & - & - \\
\hline $\mathrm{G}$ & - & - & - & - & - & - & - \\
\hline $\mathrm{H}$ & $\begin{array}{l}\text { ARG(22)/-7 } \\
\text { THR(25)/-5 }\end{array}$ & ARG(629)/-7 & $\begin{array}{c}\operatorname{ILE}(242) /-7 \\
\operatorname{ASN}(255) /-3.5\end{array}$ & \begin{tabular}{|c} 
PHE $(15) /$ \\
-2.9 \\
\end{tabular} & $\begin{array}{c}\text { ASN(105)/-7 } \\
\text { ASN(105)/-3.4 }\end{array}$ & $\begin{array}{l}\text { LYS(199)/-6.4 } \\
\text { THR(200)/-4.6 }\end{array}$ & $\begin{array}{l}\operatorname{ASN}(174) /-7 \\
\text { HIS(200)/-3.5 }\end{array}$ \\
\hline I & - & - & - & - & - & - & - \\
\hline $\mathrm{J}$ & - & $\begin{array}{c}\text { SER(577)/TYR } \\
(578) /-3.5 \\
\text { LYS }(613) / 6.6\end{array}$ & $\begin{array}{c}\mathrm{ILE}(242) / \\
\mathrm{ILE}(243) / \\
\mathrm{GLY}(249) /-3.5 \\
\mathrm{ASN}(255) /-3.5\end{array}$ & $\begin{array}{c}\operatorname{ALA}(10) / \\
-3.5\end{array}$ & $\begin{array}{l}\text { LEU(149)/-3.5 } \\
\text { ASN(152)/-3.4 }\end{array}$ & $\begin{array}{l}\operatorname{ASN}(329) /-5.3 \\
\operatorname{ASP}(192) /-6.7\end{array}$ & $\begin{array}{l}\text { TYR(299)/LYS( } \\
\text { 300)/TRP(302)/ } \\
\text { TYR(304)/-3.5 } \\
\text { LYS(95)/-3.5 }\end{array}$ \\
\hline K & $\begin{array}{l}\mathrm{LEU}(29) /-3.5 \\
\mathrm{ARG}(68) /-3.5\end{array}$ & GLY(628)/ -6.3 & \begin{tabular}{|c|} 
HIS $(181) / \mathrm{HIS}(229) /$ \\
TRP(210)/-3.5
\end{tabular} & $\begin{array}{c}\mathrm{ALA}(10) / \\
-3.3\end{array}$ & $\begin{array}{c}\mathrm{ASP}(58) /-3.5 \\
\mathrm{ARG}(60) /-12.7\end{array}$ & $\begin{array}{c}\text { LYS(199)/-5.6 } \\
\text { THR(200)/-5 }\end{array}$ & HIS(52)/-7 \\
\hline
\end{tabular}

A close-up view of the profile for Dengue virus selected protein with the investigated ligands is shown in the Figures 1-7.

Considering the data in Table III - VI, the 3D structure coordinates of seven Dengue proteins were optimized. Evaluations of binding conformation of the compounds with Dengue proteins were performed using iGEMDOCK version 2.1. From the docking study, we listed the binding affinities of the 11 compounds based on ligand binding energy. The binding pose for each ligand molecule into the Dengue viral proteins were analysed and the one having the lowest ligand binding energy with these proteins among the different poses were generated. The lower energy scores represent a better protein-ligand target binding affinity compared to a higher energy score.

Among the 11 selected compounds from onion oil, hexadecanoic was found to have the lowest binding energy especially for NS2A protein and NS3 helicase (binding energy value $=-451.87 \mathrm{kcal} / \mathrm{mol}$, respectively $-104.48 \mathrm{kcal} / \mathrm{mol}$ ) (Table III).

NS2A is a $22-k D a$ hydrophobic protein that was previously shown to be important for the viral replication and pathogenesis. NS2A participates in the viral RNA synthesis, viral assembly, virus-induced membrane formation, contributes to the production of NS1 and inhibits interferon $\alpha / \beta$ response [21]. 


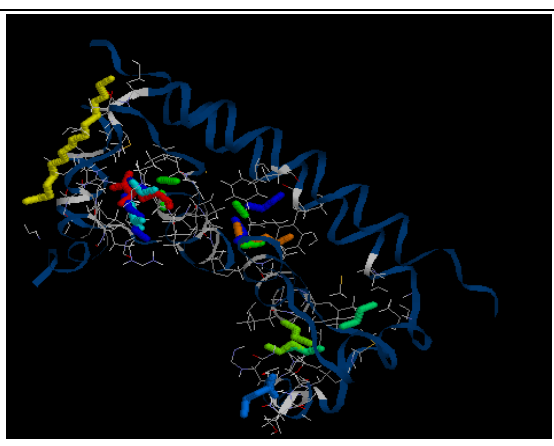

Figure 1.

Interaction of all compounds with capsid protein

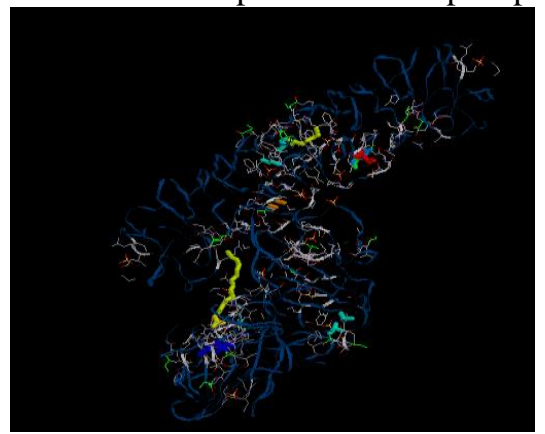

Figure 3.

Interaction of compounds with NS1 protein

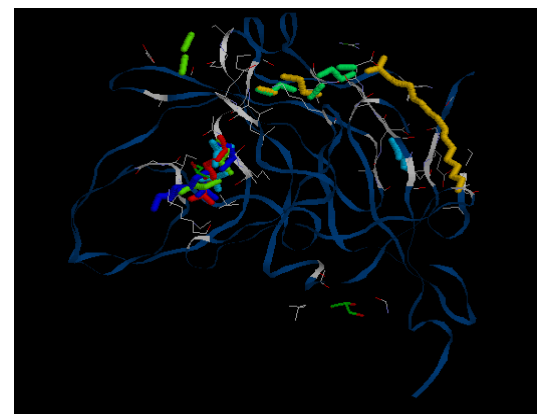

Figure 5.

Interaction of compounds with trans-membrane domain of NS2B - NS3 protease protein

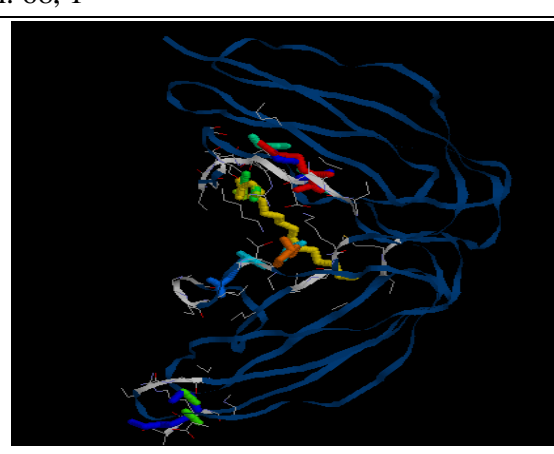

Figure 2.

Interaction of compounds with envelope protein

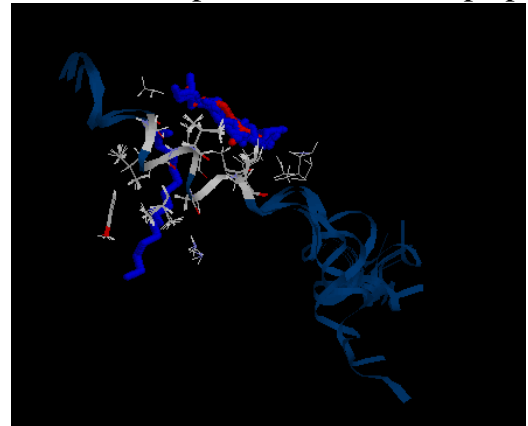

Figure 4.

Interaction of compounds with trans-membrane domain of NS2Aprotein

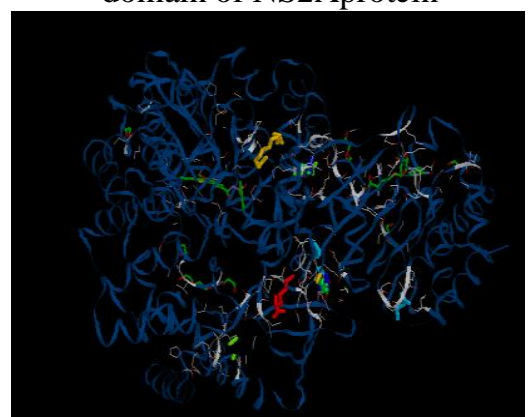

Figure 6.

Interaction of compounds with trans-membrane domain of NS5protein

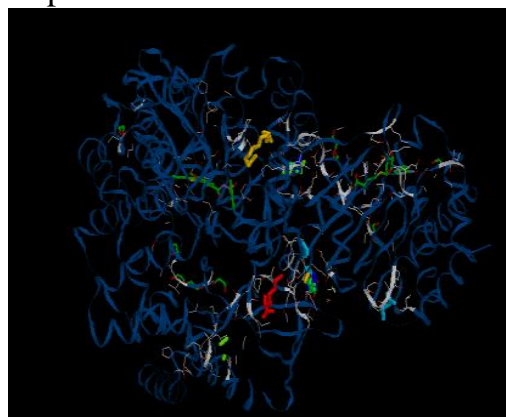

Figure 7.

Interaction of compounds with trans-membrane domain of NS3 helicase protein

The NS3 protein functions as a protease, helicase and nucleoside triphosphatase and it is essential for Dengue replication and polyprotein processing. The N-terminal 180 amino acids of NS3 make up the serine protease domain, while the $\mathrm{C}$-terminal domain encodes the helicase activity [22].
The hydrogen bond, hydrogen bond energy and, respectively, amino acid positions for each ligand were studied. Interaction analysis of binding mode of compound K for NS2A protein and NS3 helicase revealed that it forms a hydrogen bond of low energy with Ala and, respectively, two hydrogen bonds with Lys(199) and $\operatorname{Thr}(200)$ residues. 
The interaction analysis of binding mode of compounds A-K on Dengue proteins revealed that hexadecanoic acid (compound $\mathrm{K}$ ) might be the best suitable for interaction with investigated non-structural Dengue proteins.

We further analysed the docked pose for finding the binding mode of hexadecanoic acid to Dengue proteins to validate the reasonable binding conformations.

\section{Conclusions}

Docking of small molecule compounds into the binding site of a receptor and estimating the binding affinity of the complex is an important part of the structure based drug design process.

Our molecular docking studies explored the possible binding modes of 11 compounds that were chosen from the GC-MS results of Romanian onion oil on seven non-structural proteins of the Dengue virus which include the envelope protein, NS1 protein, transmembrane domain of NS2A, NS2B/NS3 protease, NS3 helicase, NS5 protein and the capsid protein.

The most active compound was $\mathrm{K}$ (hexadecanoic acid), which showed the best results in compared to. Comparing the binding energy and the binding site residues, we found that all compounds differ either in their binding modes or with the binding site residues for hydrogen bond formation. The conclusion drawn from our virtual screening and docking was that the compound $\mathrm{K}$ has the highest binding affinity with most of the proteins and it can be used as an effective drug target for Dengue virus. Even though, there are many reports in the literature on the in vitro analysis of these compounds and its antioxidant properties, but there are no in silico studies that predict the binding and active regions especially with these proteins. Our study is probably the first such attempt to predict the binding site. However, validation of our results through in vivo and in vitro experiments along with animal models will enlighten the hope for the future development of more potent drugs for treating Dengue fever.

\section{Acknowledgement}

This work was financially supported by CNCSISUEFISCDI, Postdoctoral Fellowship Programme PNII-Human Resources, project number 3/28.07.2010, code PD 149/2010.

\section{Conflict of interest}

The authors declare no conflict of interest.

\section{References}

1. Block E, Biological activity of Allium compounds: Recent results. Acta horticulturae, 2005; 688: 41-58.
2. Block E, The organosulfur chemistry of the genus Allium-implications for organic sulfur chemistry. Angew Chem Int. Edition in English, 1992; 3(9): 1135-1178.

3. Zohri AN, Abdel-Gawad K, Saber S, Antibacterial, antidermatophytic and antitoxigenic activities of onion (Allium cepa L.) oil. Microbiol Res., 1995; 150(2): 167-172.

4. Chun-Lin Y, De-Hui D, Wei-Lian H, Antimicrobial and antioxidant activities of the essential oil from onion (Allium cepa L.). Food Control, 2013; 30(1): 48-53.

5. Griffiths G, Trueman L, Crowther T, Thomas B, Smith B, Onions-a global benefit to health. Phytother Res., 2002; 16(7): 603-15.

6. Utesch D, Feige K, Dasenbrock J, Broschard TH, Harwood M, Danielewska-Nikiel B, Lines TC, Evaluation of the potential in vivo genotoxicity of quercetin. Mutat Res Genet Toxicol Environ Mutagen, 2008; 654(1): 38-44.

7. van Acker SA, van den Berg DJ, Tromp MN, Griffioen DH, Van Bennekom WP, van der Vijgh WJ, Bast A, Structural aspects of antioxidant activity of flavonoids. Free Rad Bio Med., 1996; 20(3): 331-342.

8. Ahmadi S, Rajabi Z, Marandi MV, Evaluation of the antiviral effects of aqueous extracts of red and yellow onions (Allium cepa) against avian influenza subtype H9N2. Ind J Vet Sci Tech., 2018; 2(19): 23-27.

9. Siti L, Abd K, Harisun Y, Razauden MZ, Potential anti-dengue medicinal plants: a review. J Nat Med., 2013; 67: 677-689.

10. Perera R, Kuhn RJ, Structural proteomics of Dengue virus. Curr Opin Microbiol., 2008; 11(4): 369-377.

11. Ma L, Jones CT, Groesch TD, Kihn RJ, Post CB, Solution structure of Dengue virus capsid protein reveals another fold. Proc Natl Acad Sci USA, 2004; 101: 3414-3419.

12. Xie X, Gayen S, Kang C, Yuan Z, Shi PY, Membrane topology and function of dengue virus NS2A protein. J Virol., 2013; 87: 4609-4622.

13. Mehmood M, Schar U, Ahmad N, Use of bioinformatic tools in different spheres of Lifescience. J Data Mining Genom Proteom., 2014; 5(2): 1-13.

14. Ferreira LG, Ricardo N, Oliva G, Andricopulo AD, Molecular Docking and structure based drug design strategies. Molecules, 2015; 20: 13384-13421.

15. Shivbalan S, Anandnathan K, Balasubramanian S, Datta M, Amalraj E, Predictors of spontaneous bleeding in Dengue. Indian J Pediatr., 2004; 71(1): 33-36.

16. Lengauer T, Rarey M, Computational methods for bimolecular docking. Curr Opin Struct Biol., 1996; 6: 402-406.

17. Ahmad S, Nadeem H, Muhamad SA, Naz S, Imran M, Saeed A, Synthesis, antimicrobial and $\alpha$-inhibitory potential of Mannich Bases of mercapto oxadiazoles and their molecular docking studies. Farmacia, 2018; 66(4): 708-717.

18. Jitareanu A, Boz I, Tataringa G, Zbancioc AM, Stanescu U, The effects of some cinnamic acid derivatives on the architecture of Phaseolus vulgaris roots. Rom Biotech Let., 2013; 18(3): 8317-8326.

19. Mnayer D, Fabiano-Tixier AS, Petitcolas E, Hamieh T, Nehme N, Ferrant C, Fernandez X, Chemat F, 
FARMACIA, 2020, Vol. 68, 1

Chemical composition, antibacterial and antioxidant activities of six essentials oils from the Alliaceae Family. Molecules, 2014; 19: 20034-20053.

20. Maltas E, Binding interactions of niclosamide with serum proteins. J Food Drug Anal., 2014; 22: 549555.

21. Oliveira AS, da Silva ML, Oliveira CSAF, da Silva CC, Teixeira RR, De Paula SO, NS3 and NS5 proteins: important targets for anti-dengue drug design. $J \mathrm{Braz}$ Chem Soc., 2014; 25(10): 1759-1769.

22. Xu T, Sampath A, Chao A, Wen D, Nanao M, Chene P, Vasudevan SG, Lescar J, Structure of the dengue virus helicase/nucleoside triphosphatase catalytic domain at a resolution of 2.4 A. J Virol., 2005; 79: 1027810288. 